\title{
Assessment of Three IAARD Maize Productivity In Tobadak District, Central Mamuju, Indonesia
}

\author{
Marthen Pasang Sirappa ${ }^{1 *}$, Muhtar ${ }^{1}$, Religius Heryanto ${ }^{2}$, Ketut Indrayana ${ }^{1}$ and Nurdiah Husnah ${ }^{2}$ \\ ${ }^{1}$ Researcher at the West Sulawesi Assessment Institute for Agricultural Technology, Indonesia \\ ${ }^{2}$ Extention at the West Sulawesi Assessment Institute for Agricultural Technology, Indonesia \\ *e-mail : mpsirappa@gmail.com
}

Received August 4, 2020; Revised June 18, 2021; Accepted 18 June 2021

\begin{abstract}
Assessment of three IAARD maize productivity was conducted in Tobadak sub-district, Central Mamuju. The purpose of the assessment was to determine the productivity of three IAARD hybrid maize. The area of study 3 ha, applying Integrated Crop Management (ICM) models. Varieties which assessment Nasa 29, JH 37 and JH 45, and NK 212 as comparison variety. The experiments were arranged in a randomized block design which 3 times replication. Observations were made on the growth and maize yield. Based on the results of mapping of Indonesian Center for Agricultural Land Resources Research and Development (ICALRRD), land suitability classes for maize in Central Mamuju Regency which are quite suitable (S2) and marginal (S3) are 4,308 ha and 87,889 ha respectively, while that not suitability $(\mathrm{N})$ covering an area of 193,441 ha with limiting factors including nutrient retention, nutrient availability, water availability, and root media. The studied was show that IARRD hybrid maize can increase productivity. The results showed that Nasa 29, JH 37, and JH 45 respectively gave yields $12.87 \mathrm{Mg}, 9.02 \mathrm{Mg}$, and $7.77 \mathrm{Mg} \mathrm{ha}^{-1}$, higher than the average maize yield achieved in West Sulawesi and Central Mamuju Regency, each 4.70 Mg ha-1 and 5.19 $\mathrm{Mg} \mathrm{ha}^{-1}$. Nasa 29 gave higher yields and was significantly different compared to NK $212(9.65$ $\mathrm{Mg} \mathrm{ha}^{-1}$ ) as comparison variety, and JH 37 variety was not significantly different with NK 212, but while JH 45 variety had lower results and was significantly different with NK 212. Nasa 29 and JH 37 varieties have the opportunity to be developed in Tobadak district, Central Mamuju, West Sulawesi.
\end{abstract}

Keywords: Corn, DRAINMOD, pump irrigation, tidal lowland, water management

\section{INTRODUCTION}

Accurate data and information are needed as a reference in planning, researching, and utilizing land resources for sustainable community welfare. The need for food and agro-industry can be met through various efforts, including intensification by increasing production and productivity on existing land, diversifying commodities on existing land, and extensification on new open lands.

Increasing agricultural productivity in a sustainable manner, especially food products is the focus of great attention from the latest agricultural projections. According to Hikam (2014), the phenomenon of massive climate change, increasingly critical water availability, forest and environmental degradation, deteriorating quality of resources, and a drastic decline in land fertility are some of the

J Trop Soils, Vol. 26, No. 3, 2021: 121-128

ISSN 0852-257X ; E-ISSN 2086-6682 determinants that determine the sustainability of increased agricultural productivity.

Land data information is important to know to obtain optimal plant growth and yield, as well as proper land management. IAARD through the Indonesian Center for Agricultural Land Resources Research and Development (ICALRRD) has conducted soil mapping and land suitability for semidetailed agricultural commodities on a semi-detailed scale of $1: 50,000$.

The potential of agricultural land for dryland food crops in Central Mamuju Regency based on the land suitability map and agricultural commodity direction map made by ICALRRD-IAARD is quite extensive, both for monocultures and polycultures with an intercropping system.

Decree of the Ministry of Agriculture of the Republic of Indonesia No. 259/Kpts/ RC.020/M/05/ 2020 concerning the Strategic Plan of the Ministry of Agriculture for 2020-2024 as a direction and reference in formulating agricultural development programs and activities with a focus on the strategy of superior commodities, one of which is maize. 
According to the Ministry of Agriculture (2020), the strategy in achieving this target is to position agriculture as a driving force for national development, including achieving self-sufficiency in maize through increasing land availability and use.

A big capital that can support the development and increase of agricultural production, especially food crops was dry land (Wahyunto and Shofiyati 2011). Dryland has diverse agroecosystems (biophysical and socio-economic) so that it requires management technology that is under the conditions of the agroecosystem to increase production and a sustainable agricultural system.

Las et al. (2014) stated that the existence of dry land has a strategic role in supporting development towards sustainable bio-industrial agriculture, which is shown, among other things, by the large area potential, the opportunity to increase added value through the development of commercial commodities, and can compensate agricultural production because the land is degraded, and due to land conversion. More than $66 \%$ of the existing agricultural land area is a dry land with low productivity, but it has the potential to be increased, either through increased productivity or the frequency of planting, or the area of harvest.

Maize occupies an important position in the national economy because it is a source of carbohydrates and raw materials for industry, food, and animal feed. According to Tohari et al. (2007) and Nurdin (2008), maize is the second important staple crop after rice. Domestic maize production tends to increase every year. It is estimated that more than $60 \%$ of domestic maize needs are used for feed, while for food consumption only around $24 \%$, the rest for other industrial needs and seeds (14\%).

The average maize productivity in West Sulawesi is still low 4.70 $\mathrm{Mg} \mathrm{ha}^{-1}$ (BPS Provinsi Sulawesi Barat 2018) compared to the potential yield which can reach more than $10 \mathrm{Mg} \mathrm{ha}^{-1}$ (Mejaya et al. 2014) or research/ assessment that can achieve above 7-8 $\mathrm{Mg} \mathrm{ha}^{-1}$ with the application of technological innovation (Sirappa et al. 2017; 2018).

Likewise in Central Mamuju Regency, the average corn yield is still low $5.19 \mathrm{Mg} \mathrm{ha}^{-1}$ (BPS Kabupaten Mamuju Tengah 2018), and in Tobadak District the average is $5.00 \mathrm{Mg} \mathrm{ha}^{-1}$ (BPS Kecamatan Tobadak 2019) so that productivity corn still has the opportunity to be improved by the application of technological innovations.

This research aims to provide information on land suitability for maize and the productivity of IAARD maize with an integrated crop management approach in Tobadak District, Central Mamuju Regency.

\section{MATERIALS AND METHODS}

\section{Study Sites}

This research was conducted through literature study and field research. The literature study was carried out through analysis and interpretation of land suitability maps produced by ICALRRDIAARD in 2016 for maize plants. Meanwhile, field research was conducted in Tobadak village, Tobadak district, Central Mamuju Regency in 2020.

Field research was carried out in farmer's fields on dry land. Technological innovation applied to maize cultivation is under the Integrated Crop Management (ICM) technology of maize, including the use of superior varieties and quality seeds, regulation of planting systems/spacing, balanced fertilization, integrated pest, and weed control, and harvest handling, and post-harvest well.

\section{Research Design}

The maize varieties planted were the three IAARD hybrid maize obtained from Indonesian Cereals Research Institute (ICRI) Maros, namely Nasa 29, JH 37, and JH 45 varieties, and NK 212 variety which was widely planted by local farmers as a comparison variety. The planting system used is the legowo system with a spacing of $100 \mathrm{~cm}(50$ $\times 20 \mathrm{~cm})(1$ plant per hole), balanced fertilization, namely $200 \mathrm{~kg}$ urea and $300 \mathrm{~kg}$ NPK Phonska per ha, integrated pest and weed control, and harvest handling. and post-harvest using a power thresher at harvest time.

\section{Data Analysis}

Data analysis was carried out on primary data and secondary data. Secondary data include soil data and land suitability produced by ICALRRD-IAARD, data of maize productivity from CBS of Central Mamuju District and Tobadak District. Meanwhile, primary data includes data on the growth and production of IAARD of hybrid maize as a result of a study conducted in Tobadak District, Central Mamuju in 2020.

Field research data analysis was carried out tabularly and statistically using the SAS program, then analyzed descriptively.

\section{RESULTS AND DISCUSSION}

\section{Climate and Soil Type}

The environmental factor that affects plant growth is climate. The climate elements that have the most dominant influence on plant growth are 
rainfall and temperature, as one of the criteria for determining the climatic state of an area concerning the suitability and requirements of plant growth (Ritung et al. 2011).

The characteristics of rain in an area need to be known to determine water availability and the possibility of problems and disasters related to water resources (Prawirowardoyo 1996). The same thing was stated by Arsyad et al. (2016), that the elements of climate, especially the rainfall of an area cannot be ignored.

Rain type shows the level of wetness or drought in an area based on monthly rainfall data. According to Schmidt and Ferguson (1951), the type of rainfall can be determined based on the $Q$ value, namely the ratio of the average number of dry months $(<$ $60 \mathrm{~mm} / \mathrm{month}$ ) to the average number of wet months $(>100 \mathrm{~mm} /$ month) multiplied by 100 percent. Based on the $Q$ value, the area of Central Mamuju district is included in Agro-climate B1, which is wet months 7-9 months and dry months $<2$ months.

Based on rainfall data obtained from the Agency for Meteorology Climatology and Geophysics Agency (AMCG) of Majene and statistical data of Central Mamuju Regency, the average rainfall of Central Mamuju Regency in the last 6 years (2014-2019) was $217.33 \mathrm{~mm} /$ month with the lowest rainfall $127.42 \mathrm{~mm}$ in the month August and the highest was $368.54 \mathrm{~mm} / \mathrm{month}$ in June (Figure 1). Based on this rainfall, the best planting time for corn is at the end of June and another alternative is the end of January, while this study was carried out in March 2020.

The results of mapping carried out by ICALRRD, the soil types found in Central Mamuju Regency based on the National Soil Classification (Subardja et al. 2016) consisted of 9 types of soil and reduced 15 types of soil. The 9 types of soil and their equivalents according to Keys to Soil Taxonomy (Soil Survey Staff 2014) are presented in Table 1.

The research location is placed in Tobadak District, one of the corn centers of Central Mamuju Regency. The area of Tobadak District is around $699.61 \mathrm{~km} 2$ or around $22.57 \%$ of the total area of Central Mamuju Regency (BPS Kabupaten Mamuju Tengah 2020; BPS Kecamatan Tobadak 2019). Tobadak district is located about $12 \mathrm{~km}$ from the capital of Central Mamuju Regency.

Tobadak District consists of 8 villages located in non-coastal areas and almost all of them are classified as flat, except for 2 hilly villages (Saloadak village and Sejati village) with an altitude from 0 to $500 \mathrm{~m}$ above sea level. The study was conducted in Tobadak village, Tobadak district with an area of $70.37 \mathrm{~km}^{2}(10.06 \%)$ of the total area of Tobadak district, with the status of a self-made village.

Soil types in the research location included the Kambisols and Gleisols associations, namely Eutric Kambisols (D), Distric Gleisols (F), and Gleic Kambisols (M). Eutric Kambisols have deep solum, good drainage, fine texture, slightly acidic $\mathrm{pH}$, medium Cation Exchange Capacity (CEC), and high Base Saturation (BS). District gleisols have deep solum, inhibited drainage, fine texture, acid soil $\mathrm{pH}$, low CEC, and moderate BS. Gleic Kambisols has deep soil solum, slightly hampered drainage, smooth texture, low CEC, and moderate BS.

Kambisols are soils that have undergone development, indicated by the composition of the A-Bw-C horizon, having a cambic B horizon, or an umbric A horizon, or mollic A horizon, without hydromorphic symptoms in a cross-section of 50 $\mathrm{cm}$ from the surface (Hardjowigeno 2003; Subardja et al. 2014). At the soil type level are Eutric

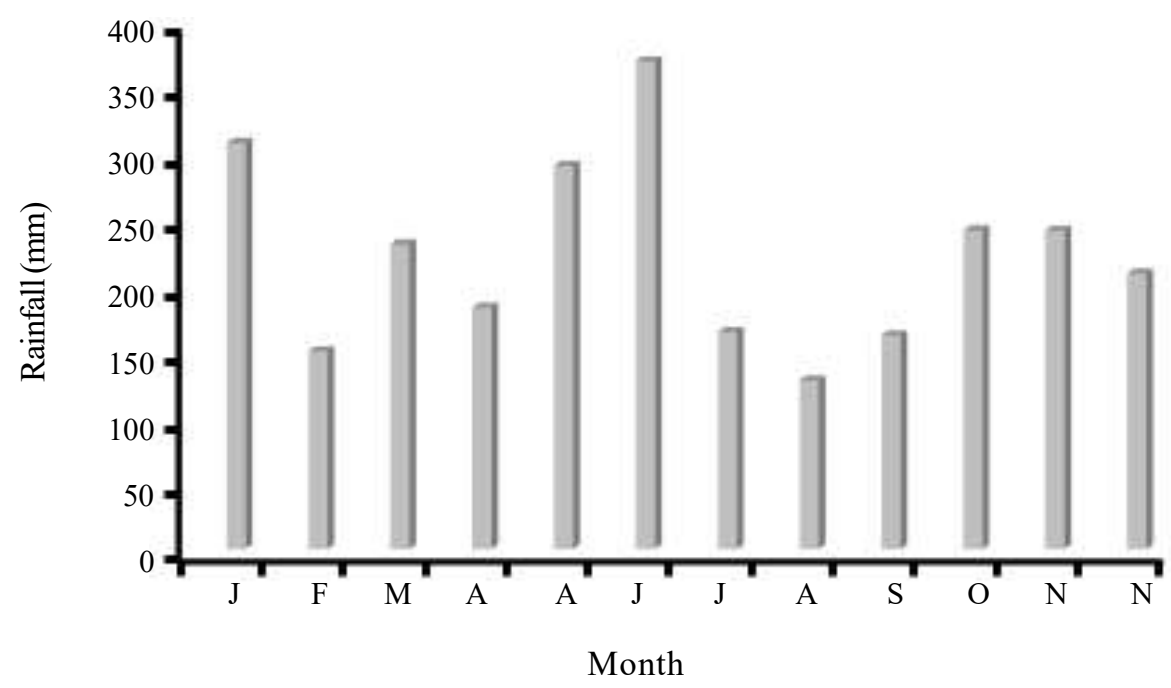

Figure 1. Rainfall Graph of Central Mamuju Regency (2014-2019). 
Table 1. Soil type and equivalent at Central Mamuju Regency.

\begin{tabular}{|c|c|c|}
\hline \multicolumn{2}{|c|}{$\begin{array}{c}\text { National Soil Classification } \\
\text { (Subardja et al. 2016) }\end{array}$} & \multirow{2}{*}{$\begin{array}{l}\text { Keys to Soil Taxonomy } \\
\text { (Soil Survey Staff 2014) } \\
\text { Subgroups }\end{array}$} \\
\hline Types & Kinds & \\
\hline Organosols & Fibric Organosols & Hemic Haplofibrists \\
\hline \multirow[t]{3}{*}{ Alluvial } & Gleic Alluvial & Typic Fluvaquents \\
\hline & & Typic Endoaquepts \\
\hline & Sulfidic Alluvial & Typic Sulfaquents \\
\hline \multirow[t]{2}{*}{ Regosols } & Gleic Regosol & Typic Psammequents \\
\hline & District Regosols & Typic Udipsamments \\
\hline Mollisols & Haplic Mollisol & Typic Haprendols \\
\hline \multirow[t]{4}{*}{ Kambisols } & Gleic Kambisol & Aquic Dystrudepts \\
\hline & & Aquic Eutrudepts \\
\hline & Dystric Kambisol & Typic Dystrudepts \\
\hline & Eutric Kambisol & Typic Eutrudepts \\
\hline \multirow[t]{4}{*}{ Gleysols } & Sulfidic Gleysol & Sulfic Endoaquepts \\
\hline & Fluvic Gleysol & Fluventic Endoaquepts \\
\hline & Dystric Gleysol & Aeric Endoaquepts \\
\hline & & Typic Endoaquepts \\
\hline Podzolic & Haplic Podzolic & Typic Hapludults \\
\hline Mediterran & Haplic Mediterran & Typic Hapludalfs \\
\hline Oxsisols & Haplic Oxsisols & Typic Hapludox \\
\hline
\end{tabular}

Source: IAARD (2016)

Kambisols and Gleic Kambisols. In the USDA soil classification system, the equivalents of Eutric Kambisols and Gleic Kambisols at the Suborder level are Udepts, Group Eutrudepts, and Subgroup Typic Eutrudepts and Aquic Eutrudepts. Typic Eutudepts are other Eutrudepts. Aquic Eutrudepts are other Eutrudepts that are at one or more horizons within $60 \mathrm{~cm}$ of the mineral soil surface, have redox depletion of 2 or less chroma, and have also aquatic conditions for part of the normal (or drained) years (Soil Survey Staff 1998).

Gleisols are developed soils that are characterized by an A-Bg-C horizon arrangement, have a lower cambic horizon with hydromorphic features to a depth of $50 \mathrm{~cm}$, are not coarse from albic materials, have no diagnostic horizon (unless buried by $50 \mathrm{~cm}$ or more new materials) other than the A horizon, the histic horizon, umbric, mollic, calcic or gypsum (Hardjowigeno 2003; Subardja et al. 2014). At the soil type level, it is classified as Distric Gleisols. In the USDA soil classification system, the District Gleisols equivalents at the Suborder level are Aquepts, Endoaquepts Group, and Subgroup Typic Endoaquepts. Typic Endoaquepts are other Endoaquepts which does not meet the requirements of any of the other Endoaquepts (Soil Survey Staff 1998).

Gleisols are developed soils that are characterized by an A-Bg-C horizon arrangement, have a lower cambic horizon with hydromorphic features to a depth of $50 \mathrm{~cm}$, are not coarse from albic materials, have no diagnostic horizon (unless buried by $50 \mathrm{~cm}$ or more new materials) other than the A horizon, the histic horizon, umbric, mollic, calcic or gypsum (Hardjowigeno 2003; Subardja et al. 2014). At the soil type level, it is classified as Distric Gleisols. In the USDA soil classification system, the Distric Gleisols equivalents at the Suborder level are Aquepts, Endoaquepts Group, and Subgroup of Typic Endoaquepts. Typic Endoaquepts are other Endoaquepts that do not meet the requirements of any of the other Endoaquepts (Soil Survey Staff 1998).

The Kambisols and Gleisols soil associations at the study site are found in alluvial plains, alluvium main material, and flat reliefs (1-3\%) with an area of about 17,830 or $6.19 \%$ of the total area of the Central Mamuju Regency (IAARD 2016).

Based on the Map of Land Resources at the Level of Scale 1: 250,000, West Sulawesi Province (ICALRRD 2014) and the results of interpretation of aerial photos at scale 1: 100,000, topographic maps scale 1: 50,000, DEM/SRTM and supported by geological maps (IAARD 2016), landform which is located in Central Mamuju Regency is divided into 6 groups. The six groups of landform are Alluvial (A), Marine (M), Fluvio Marine (B), Carst (K), Tectonic (T), and Volcanic (V). 
Most of them have relief from steep (25-40\%) to very steep ( $>40 \%$ ), namely 69,400 ha $(24.10 \%)$ and 127,966 ha $(44.45 \%)$ respectively of the total area. While others are classified as rather flat $(32,318$ ha), flat (16,810 ha), heave $(15,441 \mathrm{ha})$, hilly quite steep (13,374 ha), and wavy (10,328 ha). Tectonic, karst, and some volcanic landforms generally have hilly reliefs that are quite steep to very steep mountains (IAARD 2016).

\section{Land Suitability Class for Maize}

Land suitability classes for maize-based on soil and agro-climatic conditions in Central Mamuju Regency were dominated by not a suitable class (N) covering an area of 193,441 ha $(67.73 \%)$ with limiting factors for erosion and rooting media, and only a small part, namely around $1.51 \%(4,308 \mathrm{ha})$ are classified as moderately suitable (S2) and others are categorized as marginally suitable (S3) of $30.76 \%$ $(87,889 \mathrm{ha})$ with various limiting factors (IAARD 2016 a).

The land suitability class of moderately suitable (S2) for maize was only found in Karossa District with an area of 4,308 ha with a temperature as a limiting factor (tc). While, those classified as marginally suitable (S3) covering an area of 87,889 ha spread over 5 districts with limiting factors are erosion danger (eh), root media (rc), temperature (tc), water availability (wa), nutrient retention (nr), and nutrient availability (na). The results of land suitability class analysis for maize in Tobadak District can be seen in Table 2, while the land suitability map is in Figure 2.
Efforts made to obtain optimal plant growth and production are overcoming plant limiting factors by creating drainage channels, especially during the rainy season so that plants are not flooded, providing water during drought, improving nutrient retention by providing organic matter to increase soil capacity, or providing lime on soils that have acid soil $\mathrm{pH}$, and applying fertilizer $\mathrm{N}, \mathrm{P}$ and $\mathrm{K}$ in a balanced way to increase nutrient availability. Soemarno (2010) reported that the availability of nutrients for plants is determined by factors that affect the ability of the soil to supply nutrients and factors that affect the ability of plants to use the nutrients provided.

\section{Maize Yield}

Based on statistical data the average harvest area, production, and productivity of maize in Tobadak District, Central Mamuju Regency was $8,462 \mathrm{ha}, 42,310 \mathrm{Mg}$, and $5.00 \mathrm{Mg} \mathrm{ha}^{-1}$, respectively (BPS 2019).

The average productivity of maize achieved in Tobadak District is $5.00 \mathrm{Mg} \mathrm{ha}^{-1}$, which is still low compared to the potential for maize production which can reach more than $8 \mathrm{Mg} \mathrm{ha}^{-1}$ with the application of technological innovations, including the use of new high-yielding hybrid varieties, the use of fertilizers balanced, use of organic and ameliorant materials, spacing and planting system, managing water and weeds, controlling the pest in an integrated manner, and handling harvest and post-harvest properly.

The low average plant productivity is thought to be due to the limiting factor of plant growth under the results of the ICALRRD study where the land

Table 2. Land Suitability Classes and Limiting Factor for Corn in Central Mamuju Regency.

\begin{tabular}{|c|c|c|c|c|c|c|c|}
\hline & \multirow{3}{*}{ Symbol / Limiting Factor } & \multicolumn{6}{|c|}{ Land Suitability Class/Wide } \\
\hline & & \multicolumn{2}{|c|}{$\mathrm{S} 2$} & \multicolumn{2}{|c|}{$\mathrm{S} 3$} & \multicolumn{2}{|c|}{$\mathrm{N}$} \\
\hline & & $\mathrm{Ha}$ & $\%$ & $\mathrm{Ha}$ & $\%$ & $\mathrm{Ha}$ & $\%$ \\
\hline tc & Tc-Temperature & 4.308 & 1.51 & - & - & - & - \\
\hline eh/wa & $\begin{array}{l}\text { Eh/wa: Erosion danger, Water } \\
\text { availability }\end{array}$ & - & - & 2.213 & 0.77 & - & - \\
\hline $\mathrm{nr} / \mathrm{eh} / \mathrm{wa}$ & $\begin{array}{l}\text { Nutrient retention, Erosion danger, } \\
\text { Water availability }\end{array}$ & - & - & 10.752 & 3.76 & - & - \\
\hline $\mathrm{nr} / \mathrm{na} / \mathrm{wa}$ & $\begin{array}{l}\text { Nutrient retention, nutrient availability, } \\
\text { water availability }\end{array}$ & - & - & 22.284 & 7.80 & - & - \\
\hline nr/wa & Nutrient retention, Water availability & - & - & 18.954 & 6.64 & - & - \\
\hline $\mathrm{tc} / \mathrm{nr} / \mathrm{wa}$ & $\begin{array}{l}\text { Temperature, Nutrient retention, Water } \\
\text { availability }\end{array}$ & - & - & 31.509 & 11.03 & - & - \\
\hline $\mathrm{rc} / \mathrm{nr} / \mathrm{wa}$ & Water availability & - & - & 2.177 & 0.76 & - & - \\
\hline eh & Erosion danger & - & - & - & - & 193.168 & 67.63 \\
\hline \multirow[t]{2}{*}{$\mathrm{rc}$} & Root media & - & - & - & - & 273 & 0.10 \\
\hline & Total & 4.308 & 1.51 & 87.889 & 30.76 & 193.441 & 67.73 \\
\hline
\end{tabular}




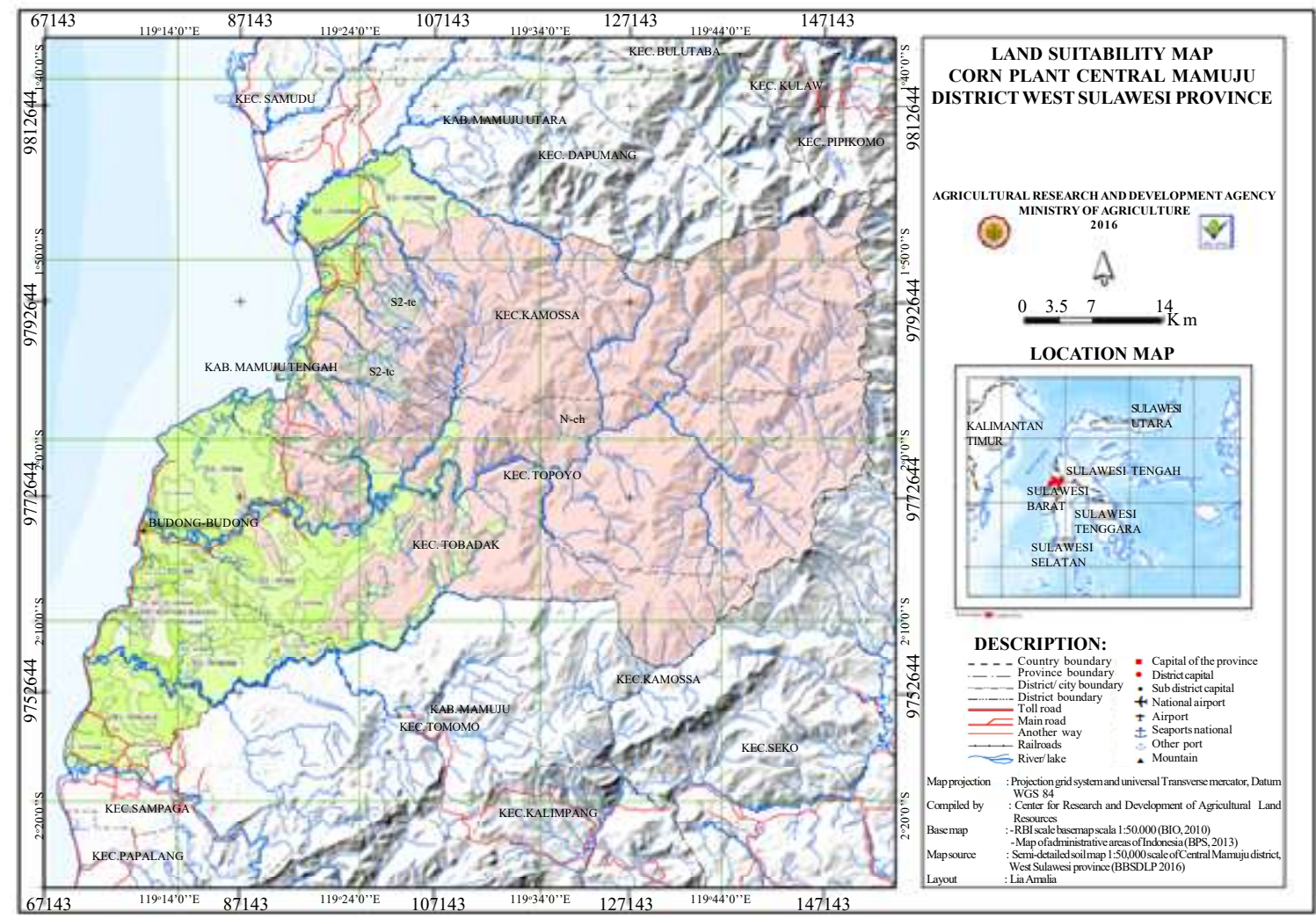

Figure 2. Map of Land Suitability for Maize in Central Mamuju Regency, West Sulawesi.

suitability class for maize is classified as marginal (S3) with limiting factors for nutrient retention, nutrient availability, root media, and water availability.

The results of observations on the yield showed that in general the IAARD maize, namely Nasa 29, JH 37, and JH 45 not show significant differences with the NK 212 as a comparison variety through the management and application of technological innovations under local agro-climatic conditions. NK 212 variety as an existing variety that is widely planted by farmers because it has wide adaptation with high production, apparently does not show a significant difference with IAARD hybrid maize with treatment under technology recommendations. The average yield of NK 212 variety as a comparison variety obtained by farmers with the same management was $9.65 \mathrm{Mg} \mathrm{ha}^{-1}$. Likewise, the results of the measurement of plant yield components showed that the IAARD hybrids maize were not significantly different from NK 212, even the IAARD hybrids Nasa 29 were higher than NK 212. The results of the three IAARD hybrids maize assess showed that Nasa 29 gave higher yields, following $\mathrm{JH} 37$ and the lowest yield was obtained on the JH 45 variety (Table 3 ).

Table 3 shows that the average yield of 3 types of IARRD hybrid maize studied in Tobadak District, Central Mamuju Regency in 2020 generally gave an increase in yields of $62-168 \%$ compared to the average yield achieved in West Sulawesi Province, Central Mamuju Regency, and Tobadak District, which have only reached $4.17 \mathrm{Mg}, 5.19 \mathrm{Mg}$ and $5.00 \mathrm{ha}^{-1}$, respectively (BPS Provinsi Sulawesi Barat 2018; BPS Kabupaten Mamuju Tengah 2019; BPS Kecamatan Tobadak 2019).

Nasa 29 variety gave dry shelled yield (water content, wc 15\%) from the conversion of the sample plant yield of $12.87 \mathrm{Mg} \mathrm{ha}^{-1}$ which was higher and significantly different than the NK 212 as comparison variety $\left(9.65 \mathrm{Mg} \mathrm{ha}^{-1}\right)$. JH 37 hybrid variety was able to give $9.02 \mathrm{Mg} \mathrm{ha}^{-1}$ yield and not significantly different from NK 212, while JH 45 variety had lower productivity compared to the comparison variety (NK 212).

The increase of maize productivity achieved in this study is more due to the application of integrated crop management technology innovations, including the use of high-yielding hybrid varieties of IAARD, namely Nasa 29, JH 37 , and $\mathrm{JH} 45$, improvement in the cropping system by using two rows of legowo with a spacing of $100 \mathrm{~cm}(50 \times 20 \mathrm{~cm})\left(1\right.$ plant hole $\left.{ }^{-1}\right)$, and the use of balanced fertilizers, namely $300 \mathrm{~kg}$ of NPK Phonska and $200 \mathrm{~kg}$ of urea ha ${ }^{-1}$ which given twice, namely at the age of 10 days and 35 days after planting. 
Table 3. An average yield of IAARD maize at Tobadak District, Central Mamuju Regency.

\begin{tabular}{lrrrr}
\hline \multirow{2}{*}{ Parameter } & \multicolumn{3}{c}{ IAARD Maize Varieties } & Average of \\
\cline { 2 - 4 } & Nasa 29 & JH 37 & JH 45 & IAARD maize \\
\hline Cob length $(\mathrm{cm})$ & $19.20 \mathrm{a}$ & $16.95 \mathrm{c}$ & $18.15 \mathrm{ab}$ & 18.10 \\
Cob diameter $(\mathrm{cm})$ & $4.43 \mathrm{~b}$ & $4.65 \mathrm{a}$ & $4.16 \mathrm{c}$ & 4.41 \\
Number of rows & $13.60 \mathrm{~b}$ & $15.60 \mathrm{a}$ & $13.80 \mathrm{~b}$ & 14.33 \\
Number of seed /row & $36.10 \mathrm{a}$ & $33.65 \mathrm{ab}$ & $31.50 \mathrm{~b}$ & 33.75 \\
Cob weight cornhusk (g) & $352.80 \mathrm{a}$ & $222.40 \mathrm{bc}$ & $191.50 \mathrm{c}$ & 255.57 \\
Cob weight without cornhusk $(\mathrm{g})$ & $307.70 \mathrm{a}$ & $201.90 \mathrm{~b}$ & $170.40 \mathrm{c}$ & 226.67 \\
Seed weight/cob (g) & $216.27 \mathrm{a}$ & $151.53 \mathrm{~b}$ & $130.52 \mathrm{c}$ & 166.11 \\
The yield of seed (\%) & $0.70 \mathrm{a}$ & $0.75 \mathrm{a}$ & $0.77 \mathrm{a}$ & 0.74 \\
Percentage of cob waste (\%) & $38.54 \mathrm{a}$ & $31.63 \mathrm{~b}$ & $31.75 \mathrm{~b}$ & 33.97 \\
Weights 100 seeds (g) & $31.77 \mathrm{~b}$ & $31.17 \mathrm{~b}$ & $33.86 \mathrm{a}$ & 32.27 \\
Yield of 10 sample plant $(\mathrm{g})$ & $2,162.70 \mathrm{a}$ & $1,515.30 \mathrm{bc}$ & $1,305.20 \mathrm{c}$ & $1,661.07$ \\
Yield wc.15\% (Mg ha $\left.{ }^{-1}\right)^{*}$ & $12.87 \mathrm{a}$ & $9.02 \mathrm{bc}$ & $7.77 \mathrm{c}$ & 9.89 \\
\hline
\end{tabular}

Remarks: ${ }^{*}$ Conversion from the yield of 10 sample plant (85\% relative yield): Harvest water content $(39.44-40.73 \%)$. The numbers followed by the same letter are not significantly different in the $0.05 \%$ Duncan test. Source: Primary Data Processed (2020).

Based on land suitability data for maize, where the land is classified as moderate suitable (S2) and according to marginally suitable (S3) with limiting factors including nutrient retention, nutrient availability, and water availability, mainly due to the influence of drainage, low $\mathrm{N}$, $\mathrm{P}$, and $\mathrm{K}$ nutrient availability is the main cause of low maize production achieved at the farm level.

Plant growth is influenced by the availability of water in the soil, where the stress of water shortages can cause a decrease in the dry weight of the plant canopy. According to Suryana et al. (2008), the use of superior varieties that are under the conditions of the agroecosystem and the application of other ICM technologies can increase yields and efficiency of production inputs.

Provision of fertilizers in a balanced manner and making drainage channels are efforts to overcome plant limiting factors so that they are expected not to become a limitation in plant growth, in addition to the application of other technologies, namely integrated weed and pest control and handling of harvest and post-harvest appropriately.

Furthermore, Yoshida (1981) reports that the availability of nutrients in the soil affects plant activity including photosynthetic activity so that plants can increase growth and yield components. Competition of plants to obtain nutrients will occur if nutrients are not available in sufficient quantities, therefore the plant population does not exceed the optimum population, namely $66,666-75,000$ plants ha $^{-1}$ (Zubachtirodin et al. 2009).

\section{CONCLUSIONS}

The land suitability class for maize in Central Mamuju Regency according to results of the ICALRRD mapping is classified as quite appropriate (S2) and according to marginal (S3) with limiting factors including nutrient retention, nutrient availability, water availability, and root media.

Assessment results from three varieties of IAARD hybrid maize (Nasa 29, JH 37, and JH 45) gave an average yield of $9.89 \mathrm{Mg} \mathrm{ha}^{-1}(7.77 \mathrm{Mg}-$ $12.87 \mathrm{Mg} \mathrm{ha}^{-1}$ ), higher than the average maize yield achieved in Central Mamuju Regency and West Sulawesi Provinces (4.17-5.19 $\left.\mathrm{Mg} \mathrm{ha}^{-1}\right)$.

Nasa 29 gave higher yields $\left(12.87 \mathrm{Mg} \mathrm{ha}^{-1}\right)$ and were significantly different compared to NK 212 hybrid maize comparison variety $\left(9.65 \mathrm{Mg}^{2} \mathrm{a}^{-}\right.$ 1), but JH 37 was not significantly different, while JH 45 was lower and significantly different compared to comparison variety.

Nasa 29 and JH 37 hybrid varieties IAARD have the potential to be developed in Tobadak, Central Mamuju, West Sulawesi.

\section{REFERENCES}

Arsyad M, Sulistiawati and AT Vistarani. 2016. Analysis of the characteristics and classification of rainfall in the maros karst area. Proceeding International Seminar on Mathematics, Science, and Computer Education, pp. 57-62.

BPS Kabupaten Mamuju Tengah. 2018. Mamuju Tengah dalam angka. Badan Pusat Statistik Kabupaten Mamuju Tengah. (in Indonesian). 
BPS Kabupaten Mamuju Tengah. 2019. Mamuju Tengah dalam angka. Badan Pusat Statistik Kabupaten Mamuju Tengah. (in Indonesian).

BPS Kabupaten Mamuju Tengah. 2020. Mamuju Tengah dalam angka. Badan Pusat Statistik Kabupaten Mamuju Tengah. (in Indonesian).

BPS Kecamatan Tobadak. 2019. Tobadak dalam angka. Badan Pusat Statistik Kecamatan Tobadak, Kabupaten Mamuju Tengah. (in Indonesian).

BPS Provinsi Sulawesi Barat. 2018. Sulawesi Barat dalam angka. Badan Pusat Statistik Provinsi Sulawesi Barat. (in Indonesian).

Hardjowigeno S. 2003. Klasifikasi Tanah Pedogenesis. Akademika Pressindo. Jakarta. 354 p. (in Indonesian)

Hikam MAS. 2014. Memperkuat Ketahanan Pangan Demi Masa Depan Indonesia 2015-2025. Publisher CV Rumah Buku. 368 p.

IAARD [Indonesian Agency for Agricultural Research and Development]. 2016. Semi Detailed Soil Map Atlas Scale 1: 50,000, Central Mamuju District, West Sulawesi Province. Indonesian Agency for Agricultural Research and Development, Ministry of Agriculture.

IAARD [Indonesian Agency for Agricultural Research and Development]. 2016 a. Atlas of Land Suitability Map and Direction of Agricultural Commodities in Central Mamuju Regency, West Sulawesi Province Scale 1: 50,000. Indonesian Agency for Agricultural Research and Development, Ministry of Agriculture.

ICALRRD [Indonesian Center for Agricultural Land Resources Research and Development]. 2014. Map of Land Resources at Review Level Scale of 1: 250,000 West Sulawesi Province. Indonesian Center for Agricultural Land Resources Research and Development, Indonesian Agency for Agricultural Research and Development, Ministry of Agriculture.

Las I, F Agus, D Nursyamsi, E Husen, T Sutriadi, Wiratno, H Syahbuddin, A Jamil, S Ritung, A Mulyani, R Hendrayana, A Dariah, E Suryani, Y Sulaeman, NL Nurida and P Rejekiningrum. 2014. Road Map penelitian dan pengembangan lahan kering. Balai Besar Penelitian dan Pengembangan Pertanian. Kementrian Pertanian. ISBN 978-602-1280-76-8. 105 p. (in Indonesian).

Mejaya MJ, RH Praptana, NA Subekti, M Aqil, A Musaddad and F Putri. 2014. Deskripsi varietas unggul tanaman pangan 2009-2014. Pusat Penelitian dan Pengembangan Tanaman Pangan. Badan Penelitian dn Pengembangan Pertanian, Kementrian Pertanian. 149 p. (in Indonesian).

Kementrian Pertanian. 2020. Rencana Strategis Kementrian Pertanian 2020-2024. Kementrian Pertanian Republik Indonesian. 148 p. (in Indonesian)

Nurdin. 2008. Optimalisasi produktifitas lahan kering melalui pengembangan system usahatani konservasi tanaman jagung di Provinsi Gorontalo. J Ilmiah Agropolitan 1: 1-15. (in Indonesian).

Prawirowardoyo S. 1996. Meteorologi. Bandung: ITB. 226 p. (in Indonesian).
Ritung S, K Nugroho, A Mulyani and E Suryani. 2011. Petunjuk teknis evaluasi lahan untuk komoditas pertanian (Edisi Revisi). Balai Besar Penelitian dan Pengembangan Sumber daya Lahan Pertanian, Badan Penelitian dan Pengembangan Pertanian, Bogor. 168 p. (in Indonesian).

Schmidt FH and JHA Ferguson. 1951. Rainfall types based on west and dry period ratios for Indonesia with Western New Guinea, Verh. No. 42. Kementrian Perhubungan dan Djawatan Meteorologi dan Geofisik, Jakarta. 212 p.

Sirappa MP, N Husnah, I Andriyani, R Heryanto, Muhtar, Abdullah, Tatong, CI Rayo, Muhlis and Sanusi, D. 2018. Study of Corn Farming System in Dryland Agroecosystems in West Sulawesi. TA Research Report. 2018. AIAT of West Sulawesi, Agricultural Research and Development Agency. 43 p. (Unpublished).

Sirappa MP, N Husnah, K Indrayana, Muhtar, Syamsuddin, R Heryant, Abd. Harris, Tatong, Abdullah and D Sanusi. 2017. A Study on the Development of Cassava and Corn Farming Systems in West Sulawesi. TA Research Report. 2017. AIAT of West Sulawesi, Agency for Agricultural Research and Development. 51 p. (Unpublished).

Soil Survey Staff. 1998. Keys to soil taxonomy. Eight Edition. USDA Natural Resources Conservation Service. Washington DC.

Soil Survey Staff. 2014. Keys to Soil Taxonomy. Twelfth Edition. USDA Natural Resources Conservation Service. Washington DC. 353 p.

Subardja DS, S Ritung S, M Anda, Sukarman, E Suryani and RE Subandiono. 2014. Petunjuk teknis klasifikasi tanah nasional. Balai Besar Litbang Sumberdaya Lahan Pertanian. Bogor. 23 p. (in Indonesian).

Subardja DS, S Ritung, M Anda, Sukarman, E Suryani and RE Subandiono. 2016. Petunjuk teknis klasifikasi tanah nasional. Edisi ke-2. Balai Besar Penelitian dan Pengembangan Sumberdaya Lahan Pertanian, Badan Penelitian dan Pengembangan Pertanian, Bogor. 60 p. (in Indonesian).

Suryana A, Suyamto, Zubachtirodin, MS Pabbage, S Saenong and IN Widiarta. 2008. Panduan pelaksanaan sekolah lapang pengelolaan tanaman terpadu (SL-PTT) jagung. Departemen Pertanian. 38 p. (in Indonesian).

Tohari, E Martono and S Somowiyarjo. 2007. Budidaya tanaman pangan utama. Universitas Terbuka. Jakarta. 39 p. (in Indonesian).

Wahyunto and R Shofiyati. 2011. Wilayah potensial lahan kering untung mendukung pemenuhan kebutuhan pangan di Indonesia, pp. 97-315. (in Indonesian).

Yoshida S. 1981. Fundamentals of rice crop science. The International Rice Research Institute. Los Baños, Laguna, Philippines. 268 p.

Zubachtirodin, S Saenong, MS Pabbage, M Azrai, D Setyorini, S Kartaatmadja and F Kasim. 2009. Pedoman umum PTT jagung. Badan Penelitian dan Pengembangan 20 p. (in Indonesian). 